\title{
Serum creatinine as a perioperative biomarker: A challenge for perioperative management and an opportunity for the Cardiothoracic Surgery Trials Network
}

\author{
John G. Augoustides, MD, FASE, FAHA
}

Despite recent advances, coronary artery bypass grafting (CABG) is still associated with adverse outcomes in patients with renal dysfunction both in the short term and in the long term, even when it is subclinical. ${ }^{1-3}$ Serum biomarkers, such as serum creatinine, enhance the identification of high-risk patients and thus may further facilitate targeting of interventions to optimize outcome after CABG. ${ }^{4}$ In fact, elevated serum creatinine has already been integrated into standard cardiac surgical risk calculators, such as the Society of Thoracic Surgeons PROM score and the EuroSCORE.

Recent evidence, however, has demonstrated that serum creatinine is not always a sensitive and specific test for renal dysfunction in patients undergoing $\mathrm{CABG}$, because it depends on factors beyond renal function, such as age, sex, and muscle mass. ${ }^{5}$ Calculation of glomerular filtration rate by accepted methods, such as the Cockroft-Gault formula or the Modification of Diet in Renal Disease equations, appears to be superior to plain serum creatinine in the identification of renal dysfunction and the prediction of adverse outcomes after CABG. ${ }^{5,6}$ In fact, the detection of renal injury in patients undergoing $C A B G$ is further enhanced by looking beyond both serum creatinine and calculated creatinine clearance. Recent evidence points to preoperative proteinuria as an independent predictor for adverse outcomes after $\mathrm{CABG}$, including acute renal dysfunction, dialysis, and prolonged stays both in the intensive care unit and in the hospital. ${ }^{7}$

This ongoing clinical refinement of serum creatinine as an outcome biomarker for CABG resembles recent progress in the world of myocardial biomarkers. The clinical utility of creatine kinase MB has been further enhanced by such biomarkers as troponin and heart-type fatty acid-binding protein. $^{8-9}$

Despite these limitations of serum creatinine as an outcome biomarker in cardiac surgery, it remains important.

\footnotetext{
From the Cardiovascular and Thoracic Section, Department of Anesthesiology and Critical Care, Perelman School of Medicine, University of Pennsylvania, Philadelphia, $\mathrm{Pa}$.

Disclosures: Author has nothing to disclose with regard to commercial support.

Received for publication Aug 30, 2011; revisions received Nov 9, 2011; accepted for publication Dec 14, 2011; available ahead of print Jan 13, 2012.

Address for reprints: John G. Augoustides, MD, FASE, FAHA, Associate Professor, Cardiovascular and Thoracic Section, Anesthesiology and Critical Care, Dulles 680, HUP, 3400 Spruce St, Philadelphia, PA, 19104-4283 (E-mail: yiandoc@hotmail.com). J Thorac Cardiovasc Surg 2012;143:523-4 $0022-5223 / \$ 36.00$

Copyright (c) 2012 by The American Association for Thoracic Surgery doi:10.1016/j.jtcvs.2011.12.025
}

The study by Pan and colleagues ${ }^{10}$ in this issue adds even more weight to the predictive importance of perioperative serum creatinine for complications after CABG. In this study, Pan and colleagues ${ }^{10}$ have demonstrated that mortality after $\mathrm{CABG}$ is predicted by subclinical increases in perioperative serum creatinine, increases that are insufficient to meet standard definitions of acute kidney injury. This observation suggests that subclinical increases in serum creatinine early after CABG might constitute an indication for prompt clinical intervention.

Given that serum creatinine and the derived creatinine clearance are sensitive risk predictors after CABG, the challenge for perioperative management is the selection of effective therapies in this setting to optimize clinical outcome by protecting the vital organs at risk. Recent consensus and evidence suggest a diverse menu of candidate interventions that merit further study in the treatment of patients after $\mathrm{CABG}$ who are considered to be at high risk on the basis of their serum creatinine profiles. ${ }^{11}$ This menu of perioperative clinical research opportunities includes but is not limited to statin therapy, intensive platelet blockade, moderate glucose control, atrial natriuretic peptide, levosimendan, and remote ischemic conditioning. ${ }^{11-15}$

Despite this progress, a revision of the role of biomarkers in predicting perioperative injury is still required for delineation not only of more sensitive levels of existing biomarkers but also of novel biomarkers for different organs. Existing biomarkers could be further refined by systematic comparisons between existing biomarkers and searches for synergistic combinations. ${ }^{8}$ As an example, troponin and B-type natriuretic peptide could be compared against each other and in combination as outcome biomarkers after CABG. ${ }^{16}$ Novel biomarkers are also in development. As an example, a recent expert commentary in the Journal has highlighted the promise of neutrophil gelatinase-associated lipocalin for detection of cardiac surgery-associated acute kidney injury. 17

The menu of research opportunities developed in this editorial showcases a major opportunity for a clinical research consortium such as the Cardiothoracic Surgery Trials Network. ${ }^{18,19}$ Multiple challenges in performing multicenter trials in cardiac surgery persist, such as lack of an infrastructure, lack of a dedicated research culture, screening, enrollment, clinical equipoise, and collaboration across specialties. ${ }^{18,19}$ The imperative is to overcome these obstacles to stay abreast with developments in patient care because the times are changing. ${ }^{20}$ 
In conclusion, Pan and colleagues ${ }^{10}$ are to be congratulated for highlighting the outcome utility of subclinical increases in serum creatinine after CABG. It is anticipated that future trials will take the leap to refine biomarkers and define perioperative interventions for mitigation of adverse clinical outcomes in adult cardiac surgical patients identified as being at high risk by such biomarkers as serum creatinine.

\section{References}

1. van Straten AH, Soliman Hamad MA, van Zundert AA, Martens EJ, Schönberger JP, de Wolf AM. Preoperative renal dysfunction as a predictor of survival after coronary artery bypass grafting: comparison with a matched general population. J Thorac Cardiovasc Surg. 2009;138:971-6.

2. Micelli A, Bruno VD, Capoun R, Romeo F, Angellini GD, Caputo M. Occult renal dysfunction: a mortality and morbidity risk in coronary artery bypass grafting surgery. J Thorac Cardiovasc Surg. 2011;141:771-6.

3. Chonchoi MB, Aboyans V, Lacroix P, Smits G, Bert T, Laskar M. Long-term outcomes after coronary artery bypass grafting: preoperative kidney function is prognostic. J Thorac Cardiovasc Surg. 2007;134:683-9.

4. Lopes NH, da Silva Paulitsch F, Pereira A, Garzillo CL, Ferreira JF, Stolf N, et al. Mild chronic kidney dysfunction and treatment strategies for stable coronary artery disease. J Thorac Cardiovasc Surg. 2009;137:1443-9.

5. Najafi M, Goodarzynejad H, Karimi A, Ghiasi A, Soltaninia H, Marzban M, et al. Is preoperative serum creatinine a reliable indicator of outcome in patients undergoing coronary artery bypass surgery? J Thorac Cardiovasc Surg. 2009;137: 304-8.

6. Mitter N, Shah A, Yuh D, Dodd-O J, Thompson RE, Cameron D, et al. Renal injury is associated with operative mortality after cardiac surgery for women and men. J Thorac Cardiovasc Surg. 2010;140:1367-73.

7. Coca SG, Jammalamadaka D, Sint K, Philbrook HT, Shilpak MG, Zappitelli M, et al. Preoperative proteinuria predicts acute kidney injury in patients undergoing cardiac surgery. J Thorac Cardiovasc Surg. Epub 2011 Nov 1.

8. Chowdhury UK, Malik V, Yadav R, Seth S, Ramakrishnan L, Kalaivani M, et al. Myocardial injury in coronary artery bypass grafting: on-pump versus off-pump comparison by measuring high-sensitivity C-reactive protein, cardiac troponin 1 , heart-type fatty acid-binding protein, creatine kinase-MB, and myoglobin release. J Thorac Cardiovasc Surg. 2008;135:1110-9, 1119.e1-10.

9. Carrier M, Pelletier LC, Martineau R, Pellerin M, Solymoss BC. In elective coronary artery bypass grafting, preoperative troponin $\mathrm{T}$ level predicts the risk of myocardial infarction. $J$ Thorac Cardiovasc Surg. 1998;115:1328-34.

10. Tolpin DA, Collard CD, Vei-Vei L, Virani SS, Allison PM, Elayda MA, et al. Subclinical changes in serum creatinine predict mortality following coronary artery bypass graft surgery. J Thorac Cardiovasc Surg. 4 Nov 2011 [Epub ahead of print].

11. Landoni G, Augoustides JG, Guarracino F, Santini F, Ponschab M, Pasero D, et al. Mortality reduction in cardiac anesthesia and intensive care: results of the first International Consensus Conference. Acta Anaesthesiol Scand. 2011; 55:259-66.

12. Collard CD, Body SC, Shernan SK, Wang S, Mangano DT; Multicenter Study of Perioperative Ischemia (MCSPI) Research Group, Inc; et al. Preoperative statin therapy is associated with reduced cardiac mortality after coronary artery bypass surgery. J Thorac Cardiovasc Surg. 2006;132:392-400.

13. Sezai A, Hata M, Niino T, Yoshitake I, Unosawa S, Wakui S, et al. Results of lowdose human atrial natriuretic peptide infusion in nondialysis patients with chronic kidney disease undergoing coronary artery bypass grafting: the NUHIT (Nihon University working group study of low dose HANP Infusion Therapy during cardiac surgery) trial for CKD. J Am Coll Cardiol. 2011;58:897-903.

14. Choi YS, Shim JK, Kim JC, Kang KS, Seo YH, Ahn KR, et al. Effect of remote ischemic preconditioning on renal dysfunction after complex valvular heart surgery: a randomized controlled trial. J Thorac Cardiovasc Surg. 2011;142:148-54.

15. Bhamidipati CM, LaPar DJ, Stukenborg GJ, Morrison CC, Kern JA, Kron IL, et al. Superiority of moderate control of hyperglycemia to tight control in patients undergoing coronary artery bypass grafting. J Thorac Cardiovasc Surg. 2011;141:543-51.

16. Fox AA, Shernan SK, Collard CD, Liu KY, Aranki S, DeSantis SM, et al. Preoperative B-type natriuretic peptide is an independent predictor of ventricular dysfunction and mortality after primary coronary artery bypass grafting. $J$ Thorac Cardiovasc Surg. 2008;136:452-61.

17. Cruz DN, Ronco C, Katz N. Neutrophil gelatinase-associated lipocalin: a promising biomarker for detecting cardiac surgery-associated acute kidney injury. J Thorac Cardiovasc Surg. 2010;139:1101-6.

18. Gardner TJ, O'Gara PT. The Cardiothoracic Surgery Network: randomized clinical trials in the operating room. J Thorac Cardiovasc Surg. 2010;139:830-4.

19. Gardner TJ, Miller MA, O'Gara PT, Gelijns AC. Building an infrastructure for clinical trials in cardiac surgery. J Thorac Cardiovasc Surg. 2011;142:265-6.

20. Cohn LH. The times they are a-changin'. J Thorac Cardiovasc Surg. 2010;140:3-4. 